DOI: $\underline{10.17805 / g g z .2019 .5 .6}$

\title{
Тезаурусный анализ и проблема атрибуции редакционных статей в «Гражданине» Достоевского (1873-1874)
}

\author{
B. Н. Захаров
}

Петрозаводский государственный университет

В статье рассматривается роль индивидуального тезауруса Ф. М. Достоевского в формировании общего корпуса текстов и редактировании текстов разных авторов в еженедельнике «Гражданин» (1873-1874). Особенности редактирования Достоевского показаны в употреблении слова «стушеваться» в данном издании, что позволяет раскрыть специфику его работы с чужсим текстом. Вмешательство в чужой текст было тотальной практикой Достоевского-редактора. Тезаурусный анализ является одним из методов в решении проблем атрибучии, средством описания авторских стилей.

В прочессе редактирования чужих текстов Достоевский зачастую перекодировал их, переводил на свой понятийный язык, вводил их в свою концептосферу, повышая таким образом уровень постановки и осмысления текущих проблем бытия. В его тезаурусе актуальны категории, которые выражают сущность явлений, становятся онтологическими. Одна из них понятие «народ» и его производные. Трактовка Достоевским концепта «народ» позволяет установить, в какой мере редактирование становилось авторством и соавторством или оставалось редакторской работой писателя.

Ключевые слова: тезаурусный анализ; Ф. М. Достоевский; тезаурус Достоевского; народная тема; еженедельник «Гражданин»; журнал «Время»; журнал «Эпоха»

\section{Thesaurus Analysis and the Issue of the Attribution of Editorials in Dostoevsky’s “Grazhdanin” (1873-1874) \\ V. N. Zakharov \\ Petrozavodsk State University}

The article examines the role of Fyodor M. Dostoevsky's individual thesaurus in the formation of the general corpus of texts and editorial revisions of texts written by different authors in the weekly periodical "Grazhdanin" ("The Citizen”, 1873-1874). The author demonstrates some features of Dostoevsky's editing by the example of using the word 'stushevat'sia' ('get embarrassed', 'disappear', etc.) in this publication. This gives an opportunity to find out the specific character 
of his work with other persons' texts. Intrusion into someone else's text was a comprehensive practice for Dostoevsky as an editor. The thesaurus analysis is a method for solving the problems of attribution and an approach to the description of writing styles.

In the course of editing texts written by other people, Dostoevsky often used to recode them, translate into his conceptual language, and introduce them into his sphere of concepts. By these means, he used to raise the level of statement and interpretation of current existential issues. In his thesaurus, actual categories are those that express the essence of phenomena and become ontological ones. One of them is the concept 'narod' ('people', 'nation') and its derivations. Dostoevsky's representation of the concept 'narod' allows to specify to what extent his editing turned out to be authorship and co-authorship or remained the writer's editorial work.

Keywords: thesaurus analysis; F. M. Dostoevsky; Dostoevsky's thesaurus; folk theme; weekly periodical "Grazhdanin"; magazine "Vremya"; magazine "Epokha"

\section{ВВЕДЕНИЕ}

К деятельности Ф. М. Достоевского давно пристало прилагательное гениальный: гениальный писатель, романист, фельетонист, читатель, наконец гениальный журналист, но - какой редактор?

Достоевский редактировал периодические издания - журналы «Время» и «Эпоха», еженедельник «Гражданин». В рутинном деле он решал оригинальные творческие задачи: создал почвенничество - новое идейное направление в русской литературе, формулировал эстетические идеи и концепции, пытался продолжить направление «Времени» в «Эпохе» и спасти журнал после смерти брата, в 1873-1874 гг. преобразовал еженедельник «Гражданин» в орган «петербургского славянофильства», сочинял и сам издавал «Дневник Писателя».

Редактирование этих изданий проходило в разных условиях: в 18601864 гг., благодаря поддержке брата, Достоевский был свободен в реализации редакционных требований. Братья создали журнал, в котором были анонимные рубрики «Внутреннее обозрение», «Наши домашние дела», «Политическое обозрение» (их вели постоянные сотрудники), анонимны были фельетоны, многие критические и публицистические статьи, которые имели редакционный характер. Лишь некоторые авторы удостаивались права литературной подписи. Анонимность критики и публицистики была обязательным условием сотрудничества для многих авторов во «Времени».

О том, что редакционная критика и полемика были заботой именно Федора Достоевского, свидетельствует история второго журнала братьев До- 
стоевских. «Эпоха» началась без Ф. Достоевского, который с ноября 1863 по апрель 1864 г. жил преимущественно в Москве, заботясь об умирающей жене. В составе первых четырех номеров, выпущенных в марте — июне 1864 г. М. Достоевским, почти все статьи подписаны полными авторскими именами или узнаваемыми псевдонимами. Приступив к редактированию журнала с пятого номера, Достоевский начал вводить редакционные и анонимные материалы, подав пример своей полемической статьей «Господин Щедрин, или Раскол в нигилистах», восстановил рубрики «Наши домашние дела» и «Политическое обозрение», но многое не успел: за шесть месяцев он должен был выпустить семь номеров.

Так же было и в процессе издания «Гражданина». Если сравнить еженедельник Мещерского до и после редакторства Достоевского, сразу обнаруживается склонность гениального романиста и фельетониста к редакционным статьям.

\section{Ф. М. ДОСТОЕВСКИЙ - РЕДАКТОР «ГРАЖДАНИНА»}

Редакторская работа Достоевского в «Гражданине» сложнее, чем она может предстать воображению современного читателя. Вся редакция состояла из нескольких человек: два редактора - В. П. Мещерский и Ф. М. Достоевский, секретарь В.Ф. Пуцыкович, сотрудники А. У. Порецкий и москвич И. Ю. Некрасов, авторы, писавшие «даровые» статьи: К. П. Победоносцев, Т. И. Филиппов. Они обеспечивали основной корпус текстов. От типографии в издании участвовали метранпаж М. А. Александров и корректор В. В. Тимофеева. Заботами этих людей каждый понедельник читатели получали новый номер «Гражданина». «Внештатные» авторы и корреспонденты еженедельника работали с редакторами - собственником и издателем. Достоевский предпочитал, чтобы решение о публикации статей принимал Мещерский, он же редактировал статьи, одобренные редактором-собственником. В. А. Викторович справедливо назвал возникший в процессе редактирования корпус текстов «Гражданина» «коллективным творчеством» (Викторович, 2015).

Редакционные статьи в «Гражданине» - особый жанр, в котором доминировали установки редактора-собственника и редактора-издателя, но не всегда. Мещерский избегал править Достоевского, но Достоевский правил всех, в том числе и Мещерского. Под всеми подписанными и анонимными статьями газеты-журнала «Гражданин» не просто так стоит подпись «Редакторъ-Издатель $\Theta$. М. Достоевскій». Он печатал лишь те статьи, с которыми был согласен, под которыми он мог поставить свою подпись редактора ${ }^{1}$.

\footnotetext{
${ }^{1}$ О статусе редакционных статей в изданиях Достоевского см.: Захаров, 2017.
} 
Как появлялись редакционные статьи? Иногда это был заказ одного из редакторов с ясно выраженным заданием сотруднику или автору, но, как правило, редакционные статьи писали Мещерский и Достоевский. Все они были результатом обсуждения темы на обедах или журфиксах князя Мещерского, совещаний в типографии или редакции еженедельника. В пылу дискуссий обычно доминировал Достоевский, он же зачастую и правил тексты.

В «Гражданине» есть статьи, которые подписаны другими именами, но переписаны, переделаны или «обделаны» редактором. Здесь важно установить, в какой мере редактирование становится авторством и соавторством или остается редакторской работой.

Одним из методов атрибуции и способов выявления редактирования текста является тезаурусный анализ. Казалось бы, мы пользуемся одними и теми же словами, но по-разному их понимаем и употребляем. У каждого автора свой тезаурус. Он не статичен, а динамичен.

Корпус текстов «Гражданина» представляет собой множество индивидуальных тезаурусов. Задачей редактора была их интеграция. В чем выражается их целостная общность?

У Достоевского были свои характерные «слова» и «словечки», по его выражению.

Одно из них - слово стушеваться. Достоевский ставил себе в заслугу то, что он ввел это слово в русскую литературу. Об этом он рассказал в одной из главок «Дневника Писателя» за ноябрь 1877 год, которая так и называется «История глагола “стушеваться”».

В «Гражданине» 8 употреблений слова стушеваться: один раз в авторском тексте Достоевского, семь раз в текстах, подписанных другими авторами или их псевдонимами: Л. Ю. Кохнова, Архимандрит Григорий Палама, Недолин [М.А.Сакс], литера «Л.», В. Пелешевский, Святослав-Сольнский [В. П. Мещерский], Павель Павловъ [П. П. Вяземский].

Первый раз слово встречается в «Дневнике Писателя», где Достоевский воспроизвел слова В. Г. Белинского: «Да, повђрьте же, наивный вы человъкъ, набросился онъ опять на меня, повърьте же, что вашъ Христосъ, если бы родился въ наше время, былъ бы самымъ незамьтнымъ и обыкновеннымъ человъкомъ; такъ и стушевался бы при нынъшней наукъ и при нынъшнихъ двигателяхъ человъчества» ${ }^{2}$ (Гражданин, 1873а: Электронный ресурс; здесь и далее выделения в цитатах жирным шрифтом мои. - B. 3.).

\footnotetext{
${ }^{2}$ Примечательный анахронизм: из рассказа Достоевского 1873 г. следует, что Белинский употребил слово стушеваться в начале июня 1845 г., между тем как позже критик похвалил начинающего писателя за это слово во время чтения первых глав «Двойника», которое состоялось в начале декабря 1845 г.
} 
Второй раз - в статье Л. Ю. Кохновой «Отвђтъ женщины на призывъ “Гражданина”: “К дълу!”»: «Женщина по самой натурђ своей вовсе не склонна становиться на первый планъ, она всегда готова стушеваться и никогда сама по себъ не станетъ искать самостоятельности. Однимъ словомъ, женщина всегда готова отдать свою самостоятельность, если ее возьмутъ» (Гражданин, 1873f: Электронный ресурс).

Третий - в примечании к статье архимандрита Григория Паламы «Еще о болгарскомъ вопрось. (Окончаніе)»: <Примечание:> «Церковное подчиненіе не есть національное или племенное, и самыя слова эти, принадлежащія политическому языку и свђтской дипломатіи, никогда не существовали и не произносились въ церкви Христовой. Національное начало совершенно стушевывалось въ церкви подъ однимъ общимъ именемъ “православныхъ христіанъ”, и если мы встрьчаемъ укоренившимся въ обычаь названіе “греко-восточная”, или просто “греческая церковь”, то въ этомъ смысль названіе “греческаго” служить синонимомъ «православнаго» и составляеть отличіе и знакъ религіи болье, чЊмъ національности» (Гражданин, 1873g: Электронный ресурс).

Четвертый - в рассказе Недолина <М. А. Сакса > «Дьячокъ»: «Появленіе этой женщины, ея манеры, холодность и гордость озадачили меня до того, что весь остальной вечеръ я быль чуть не менъе взволнованъ, какъ и бъдный Софронъ; онъ, впрочемъ, былъ совершенно придавленъ, какъ-то стушевался, съежился» (Гражданин, 1873h: Электронный ресурс).

Пятый - в письме к редактору «Заметка о высших женских курсах в Москве» (подпись: Л.): «Правда, двъ-три слушательницы явились подстриженными, въ очкахъ и въ костюмъ похожемъ на мужской сюртукъ, но онъ должны были стушеваться и кажется куда-то исчезли. Здоровыя начала взяли верхъ» (Гражданин, 1873і: Электронный ресурс).

Шестой - в статье, подписанной «Пелешевскій» (без инициалов), «Наглядный просмотръ отчетовъ нъкоторыхъ нашихъ желъзныхъ дорогъ за 1872 годъ»: «Размашистыя смъты иныхъ изъ нашихъ гарантированныхъ желъзныхъ дорогъ дають право думать, что иногда просто недосугъ всматриваться въ безконечныя цифры отчетовъ желъзныхъ дорогъ и смътнаго предложенія на будущій годъ. Стушевываются какъ-то незамътно всякія экономическія точки зрънія и служебное соблюденіе казенныхъ интересов передъ копотливостью работы» (Гражданин, 1873k: Электронный ресурс).

Седьмой - в цикле статей Святослава-Солынского $<$ В. П. Мещерский> «Неизбъжныя размышленія»: «Въ прекрасный день эти три проекта слились въ одинь - правительственный, и съ этой минуты мы перестали слышать о крестьянскомъ вопросъ съ точки зрьнія дворянской или литературной, и изъ трехь группъ людей остались только двђ - петербург- 
скія: правительство и литература; помњщики, какъ группа мыслящихъ людей, стушевались и съ той поры замерли повидимому на въки» (Гражданин, 18731: Электронный ресурс).

Восьмой - в рецензии Павла Павлова <П. П. Вяземский $>$ из цикла «Замђтки досужаго читателя»: «...казалось бы рђчь идетъ объ одной изъ тъхъ бльдныхъ, туманныхъ, безцвђтныхъ личностей, которыхъ такъ часто встрђчаешь въ жизни, которымъ предназначено самою судьбою стушевываться на съромъ, однообразномъ фонъ посредственности, въ которомъ, какъ ихъ ни разглядывай, не найдешь ничего выступающаго надъ уровнемъ обыкновеннаго. На дъль выходитъ не такъ» (Гражданин, 1874: Электронный pecypc).

Итак, восемь авторов, употребивших в одно и то же время в одном издании редкое в русском языке слово! Подобный эффект впечатляет. Можно допустить, что всё произошло случайно, но вероятность таких совпадений ничтожна мала. Появление слова стушеваться явно не случайно. Вряд ли Достоевский в личном общении увлекал этим словом каждого из семи авторов. Скорее всего появление слова стушеваться было результатом редактирования им чужого текста.

Особо в этом перечне словоупотреблений стоит примечание к статье архимандрита Григория Паламы «Еще о болгарском вопросе». В статье есть авторские и редакционные примечания. Данное примечание, по форме авторское, имеет явные признаки стилистической правки редактора.

Приведенные примеры показывают, что редакторское вмешательство было тотальной практикой, излюбленный Достоевским неконцептуальный глагол стушеваться обнаруживается в чужих авторских текстах, который после правки редактора не становился текстом Достоевского.

Одним из концептов с высокой частотностью употребления в статьях разных авторов еженедельника «Гражданин» было существительное народ и его производные. Из 3368 употреблений 63 приходится на прилагательное международный, 1360 - на прилагательное народный, 1945 употреблений остается на существительное народ.

Hародным в статьях авторов «Гражданина» был дух, язык, характер, ум, смысл, обычай, вкус, образ, тон, вопрос, миф, эпос, гимн, говор, прогресс, труд, доход, капитал, быт, кредит, трибун, гений, учитель, театр, праздник, календарь, разврат и т. д.

Народной - жизнь, речь, поэзия, словесность, литература, история, сказка, вера, нравственность, совесть, мудрость, деятельность, производительность, школа, читальня, армия, сила, черта, темнота, тропа, масса, будущность, воля, встреча, распущенность, кухня, гигиена и др. 
Hароднымм было сознание, творчество, чувство, самосознание, воображение, выражение, образование, просвещение, невежество, благосостояние, право, дело, учреждение, голосование, представительство, самоуправление, потребление, здравие, пьянство, продовольствие, богатство, хозяйство, верование, воспитание, сказание, училище, стремление, голосование, представительство, обращение, развитие, собрание, зрелище, бедствие, большинство и Т. П.

Существительное народ используется в разных значениях: в человечестве - это «племена» («народы мира»), для власти - подданные, для высшего света - все, кто находится вне их круга, для дворян - недворяне, для образованных сословий - «простой народ»: крестьяне, духовенство, купцы, мещане, мастеровые; в быту - люди, толпа. В таких типичных значениях слово предстоит в текстах всех авторов.

Что у Достоевского?

Обратимся к подписанным автором текстам, и прежде всего к «Дневнику Писателя» за 1873 год.

Для Достоевского народ не просто понятие, не только концепт, а идеологема (выражение «чисто русской идеи»).

По его убеждению, русское барство отошло от народа, потеряло Бога, презирает народ, любит его отрицательно, вместо реального воображает «какой-то идеальный народ»: «ОтдЂлясь оть народа, они естественно потеряли и Бога. Безпокойные изъ нихъ стали атеистами; вялые и спокойные - индиферентными. Къ русскому народу они питали лишь одно презрьніе, воображая и въруя въ то же время что любятъ его и желаютъ ему всего лучшаго. Но они любили его отрицательно, воображая вмъсто него какой-то идеальный народъ, - какимъ-бы долженъ быть по ихъ понятіямъ русскій народъ» (Гражданин, 1873а: Электронный ресурс).

Таковы Герцен и «старые люди».

В русском народе есть глубокие, зачастую бессознательные идеи, которые характеризуют его: «Есть идеи невысказанныя, безсознательныя и только лишь сильно чувствуемыя; такихъ идей много какъ бы слитыхъ съ душой человЂка. Есть онђ и въ цъломъ народђ, есть и въ человђчествђ взятомъ какъ цҺлое. Пока эти идеи лежать лишь безсознательно въ жизни народной и только лишь сильно и вьрно чувствуются, - до тьхъ порь только и можеть жить сильнъйшею живою жизнью народъ. Въ стремленіяхъ къ выясненію себъ этихъ сокрытыхъ идей и состоитъ вся энергія его жизни. Чъмъ неколебимъе народъ содержить ихъ, чъмъ менђе способенъ измънить первоначальному чувству, чЊмъ менЊе склоненъ подчиняться различнымъ и ложнымъ толкованіямъ этихъ идей, тъмъ онъ могучъе, крђпче, счастливъе. Къ числу такихъ сокрытыхъ въ русскомъ народъ идей - идей русскаго народа - и 
принадлежить названіе преступленія несчастіемъ, преступниковъ несчастными.

Идея эта чисто русская. Ни въ одномъ европейскомъ народъ ея не замъчалось. На западъ провозглашають ее теперь лишь философы и толковники. Народъ же нашъ провозгласилъ ее еще задолго до своихъ философовъ и толковниковъ. Но изъ этого не сльдуетъ чтобы онъ не могъ быть сбитъ съ толку ложнымъ развитіемъ этой идеи толковникомъ, временно по крайней мърђ, съ краю. Окончательный смысль и посльднее слово останутся безъ сомнънія всегда за нимъ, но временно - можеть быть иначе.

Короче: этимъ словомъ “несчастные” народъ какъ бы говорить “несчастнымъ”: “Вы согрђшили и страдаете, но и мы въдь грђшны. Будь мы на вашемъ мъсть, - можеть и хуже бы сдълали. Будь мы получше сами, можетъ и вы не сидъли бы по острогамъ. Съ возмездіемъ за преступленія ваши вы приняли тяготу и за всеобщее беззаконіе. Помолитесь объ насъ и мы объ васъ молимся. А пока берите, “несчастные”, гроши наши; подаемъ ихъ чтобы знали вы что васъ помнимъ и не разорвали съ вами братскихъ связей”» (Гражданин, 1873b: Электронный ресурс).

Достоевский объясняет слова и формулирует идеи: «...народъ не отрицаетъ преступленія и знаетъ, что преступникъ виновенъ. Народъ знаетъ только что и самъ онъ виновенъ вмъсть съ каждымъ преступникомъ. <...> Воть что̀, невысказанно, ощущаетъ сильнымъ чувствомъ въ своей сокрытой идеђ о несчастіи преступника русскій народъ» (там же).

Порицая оправдания преступников в суде присяжных, Достоевский объясняет: «Прямо скажу: строгимъ наказаніемъ, острогомъ и каторгой вы можеть быть половину спасли-бы изъ нихъ. Облегчили бы ихъ, а не отяготили. Самоочищеніе страданіемъ легче, легче говорю вамъ, чЂмъ та участь, которую вы дълаете многимъ изъ нихъ сплошнымъ оправданіемъ ихъ на судъ. Вы только вселяете въ его душу цинизмъ, оставляете въ немъ соблазнительный вопросъ и насмђшку надъ вами же. Вы не върите? Надъ вами же, надъ судомъ вашимъ, надъ судомъ всей страны! Вы вливаете въ его душу безвъріе въ правду народную, въ правду Божію; оставляете его смущеннаго...» (там же).

Он уверен: «...если бы даже, говорю я, произошло какое нибудь уже настоящее, несомнънное несчастіе народное, какое нибудь огромное паденіе, большая бъда - то и туть народъ спасеть себя самъ, себя и насъ, какъ уже неоднократно бывало съ нимъ, о чемъ свидътельствуетъ вся его исторія. Вотъ моя мысль» (Гражданин, 1873с: Электронный ресурс).

Достоевский утверждает: «...самая главная, самая коренная духовная потребность русскаго народа - есть потребность страданія, всегдашняго и неутолимаго, вездъ и во всемъ. <..> У русскаго народа даже въ счастьи 
непремънно есть часть страданія, иначе счастье его для него не полно» (Гражданин, 1873d: Электронный ресурс).

Есть объяснение этой потребности: «Можеть быть единственная любовь народа русскаго есть Христосъ и онъ любить образъ Его по своему, то есть до страданія. Названіемъ же православнаго, то есть истиннђе всђхъ исповъдующаго Христа, онъ гордится болђе всего. Повторю: можно очень много знать безсознательно» (там же).

«...помощь духовенства народу никогда еще не была такъ настоятельно необходима. Мы переживаемъ самую смутную, самую неудобную, самую переходную и самую роковую минуту можеть быть изъ всей исторіи русскаго народа» (Гражданин, 1873е: Электронный ресурс).

«...никакимъ развратомъ, никакимъ давленіемъ и никакимъ униженіемъ не истребишь, не замертвишь и не искоренишь въ сердцђ народа нашего жажду правды, ибо эта жажда ему дороже всего» (там же).

Наконец Достоевский открывает читателю свое знание тайны народа: «И не заключается ли все, все чего ищетъ онъ — въ православіи? Не въ немъ ли одномъ и правда и спасеніе народа русскаго, а въ будущихъ вЂкахъ и для всего человъчества? Не въ православіи ли одномъ сохранился божественный ликъ Христа во всей чистоть? И можеть быть главньйшее предъизбранное назначеніе народа русскаго въ судьбахъ всего человьчества и состоить лишь въ томъ, чтобъ сохранить у себя этоть божественный образъ Христа во всей чистоть, а когда придеть время, - явить этоть образъ міру, потерявшему пути свои!» (там же).

О чем бы ни писал автор, например, о пьянстве или сквернословии хмельного народа, Достоевский оригинален или парадоксален в своих суждениях: «...народъ нашъ цђломудренъ даже и сквернословя...» (Гражданин, 1873j: Электронный ресурс).

«Народъ сквернословитъ зря, и часто не объ томъ совсьмъ говоря. Народъ нашъ не развратенъ, а очень даже цъломудренъ, не смотря на то, что это безспорно самый сквернословный народъ въ цђломъ мірђ, — и объ этой противоположности право стоить хоть не множко подумать» (там же).

На каторге Достоевскому открылось «непосредственное соприкосновеніе съ народомъ, братское соединеніе съ нимъ въ общемъ несчастіи, понятіе что самъ сталъ такимъ же какъ онъ, съ нимъ сравненъ, и даже приравненъ къ самой низшей ступени его» (Гражданин, 1873m: Электронный ресурс).

Это произошло не сразу, не вдруг, а «постепенно и посль очень-очень долгаго времени» (там же). 
Автора роднят с народом традиции его семейства, русского и благочестивого, любовь родителей, знание Евангелия «чуть не сь перваго дътства», чтение Карамзина, посещения Кремля и московских соборов (там же).

Никто из современников гения так не писал о народе.

У Достоевского есть разные тексты, в том числе и те, в которых нет этого пафоса и градуса поэзии, профетизма и глубины, но его слово всегда готово к внутреннему преображению и воскрешению.

Трактовка автором концепта народ зависит не только от конкретной речевой ситуации, но и от жанра: в «Иностранных событиях» народ - прежде всего субъект национальной и мировой политики.

У Достоевского народ — онтологическое явление и понятие.

\section{ЗАКЛЮЧЕНИЕ}

В тезаурусе Достоевского актуальны и другие онтологические категории, которые выражают сущность явлений: Россия, Бог, Христос, жизнь, истина, свобода, воля, совесть, правда, ложь, страдание, вера, безверие, атеизм, добро, зло, ум, сердце, радость, счастье, любовь, грех, вина, преступление, наказание, исповедь... и т. д. Их нужно выявить в корпусе текстов «Гражданина», сравнить индивидуальные тезаурусы авторов еженедельного издания.

Тезаурусный анализ является одним из методов решения проблем атрибуции, средством описания авторских стилей. Исправляя и редактируя чужие тексты, Достоевский перекодировал их, переводя на свой понятийный язык, вводя их в свою концептосферу, повышая таким образом уровень постановки и осмысления текущих проблем бытия.

\section{СПИСОК ЛИТЕРАТУРЫ}

Викторович, В. А. (2015) Достоевский. Коллективное. «Гражданин» как творчество редактора [Электронный ресурс] // Неизвестный Достоевский. № 4. C. 11-20. URL: http://unknown-dostoevsky.ru/files/redaktor_pdf/14537102 11.pdf [архивировано в WaybackMachine] (дата обращения: 19.12.2019). DOI: 10.15393/j10.art.2015.2502

Захаров, В. Н. (2017) О статусе редакционных статей в изданиях Достоевского [Электронный ресурс] // Неизвестный Достоевский. № 1. С. 3-17. URL: http://unknown-dostoevsky.ru/files/redaktor_pdf/1493122152.pdf [архивировано в WaybackMachine] (дата обращения: 19.12.2019). DOI: 10.15393/j10. art.2017.3083

Гражданин. (1873a) № 1. 1 января [Электронный ресурс] // Philolog.ru. URL: http://philolog.petrsu.ru/fmdost/grajd/1873/1janN1.htm [архивировано в WaybackMachine] (дата обращения: 15.10.2019). 
Гражданин. (1873b) № 2. 8 января [Электронный ресурс] // Philolog.ru. URL: http:/philolog.petrsu.ru/fmdost/grajd/1873/8janN2.htm [архивировано в WaybackMachine] (дата обращения: 15.10.2019).

Гражданин. (1873c) № 3. 15 января [Электронный ресурс] // Philolog.ru. URL: http://philolog.petrsu.ru/fmdost/grajd/1873/15janN3.htm [архивировано в WaybackMachine] (дата обращения: 15.10.2019).

Гражданин. (1873d) № 4. 22 января [Электронный ресурс] // Philolog.ru. URL: http://philolog.petrsu.ru/fmdost/grajd/1873/22janN4.htm [архивировано в WaybackMachine] (дата обращения: 15.10.2019).

Гражданин. (1873e) № 8. 19 февраля [Электронный ресурс] // Philolog.ru. URL: http://philolog.petrsu.ru/fmdost/grajd/1873/19febN8.htm [архивировано в WaybackMachine] (дата обращения: 15.10.2019).

Гражданин. (1873f) № 13. 26 марта [Электронный ресурс] // Philolog.ru. URL: http://philolog.petrsu.ru/fmdost/grajd/1873/26marN13.htm [архивировано в WaybackMachine] (дата обращения: 15.10.2019).

Гражданин. (1873g) № 14. 2 апреля [Электронный ресурс] // Philolog.ru. URL: http://philolog.petrsu.ru/fmdost/grajd/1873/2aprN14.htm [архивировано в WaybackMachine] (дата обращения: 15.10.2019).

Гражданин. (1873h) № 15-16. 16 апреля [Электронный ресурс] // Philolog.ru. URL: http://philolog.petrsu.ru/fmdost/grajd/1873/aprN1516.htm [apхивировано в WaybackMachine] (дата обращения: 15.10.2019).

Гражданин. (1873i) № 27. 2 июля [Электронный pecypc] // Philolog.ru. URL: http:/philolog.petrsu.ru/fmdost/grajd/1873/2julN27.htm [архивировано в WaybackMachine] (дата обращения: 15.10.2019).

Гражданин. (1873j) № 32. 6 августа [Электронный ресурс] // Philolog.ru. URL: http:/philolog.petrsu.ru/fmdost/grajd/1873/6auN32.htm [архивировано в WaybackMachine] (дата обращения: 15.10.2019).

Гражданин. (1873k) № 39. 24 сентября [Электронный ресурс] // Philolog.ru. URL: http://philolog.petrsu.ru/fmdost/grajd/1873/24seN39.htm [архивировано в WaybackMachine] (дата обращения: 15.10.2019).

Гражданин. (1873l) № 40. 1 октября [Электронный ресурс] // Philolog.ru. URL: http:/philolog.petrsu.ru/fmdost/grajd/1873/10cN40.htm [архивировано в WaybackMachine] (дата обращения: 15.10.2019).

Гражданин. (1873m) № 50. 10 декабря [Электронный ресурс] // Philolog.ru. URL: http://philolog.petrsu.ru/fmdost/grajd/1873/10deN50.htm [apхивировано в WaybackMachine] (дата обращения: 15.10.2019).

Гражданин. (1874) № 9. 4 марта [Электронный pecypc] // Philolog.ru. URL: http://philolog.petrsu.ru/fmdost/grajd/1874/74n09.htm [архивировано в WaybackMachine] (дата обращения: 15.10.2019). 
Дата поступления: 22.10.2019 г.

\section{REFERENCES}

Viktorovich, V. A. (2015) Dostoevskii. Kollektivnoe. «Grazhdanin» kak tvorchestvo redaktora [Dostoevsky. The collective. "Grazhdanin" as a creative work of the editor]. Neizvestnyi Dostoevskii, no. 4, pp. 11-20. [online] Available at: http://unknown-dostoevsky.ru/files/redaktor_pdf/1453710211.pdf [archived in WaybackMachine] (accessed 19.12.2019). DOI: 10.15393/j10.art.2015.2502

Zakharov, V. N. (2017) O statuse redaktsionnykh statei v izdaniiakh Dostoevskogo [On the status of editorials in Dostoevsky's periodicals]. Neizvestnyi Dostoevskii, no. 1, pp. 3-17. [online] Available at: http://unknown-dostoevsky.ru/files/ redaktor_pdf/1493122152.pdf [archived in WaybackMachine] (accessed 19.12. 2019). DOI: $\underline{10.15393 / j 10 . a r t .2017 .3083}$

Grazhdanin. (1873a) No.1, January 1. Philolog.ru [online] Available at: http://philolog.petrsu.ru/fmdost/grajd/1873/1janN1.htm [archived in WaybackMachine] (accessed 15.10.2019).

Grazhdanin. (1873b) No. 2, January 8. Philolog.ru [online] Available at: http://philolog.petrsu.ru/fmdost/grajd/1873/8janN2.htm [archived in WaybackMachine] (accessed 15.10.2019).

Grazhdanin. (1873c) No. 3, January 15. Philolog.ru [online] Available at: http://philolog.petrsu.ru/fmdost/grajd/1873/15janN3.htm [archived in Wayback Machine] (accessed 15.10.2019).

Grazhdanin. (1873d) No. 4, January 22. Philolog.ru [online] Available at: http://philolog.petrsu.ru/fmdost/grajd/1873/22janN4.htm [archived in Wayback Machine] (accessed 15.10.2019).

Grazhdanin. (1873e) No. 8, February 19. Philolog.ru [online] Available at: http://philolog.petrsu.ru/fmdost/grajd/1873/19febN8.htm [archived in Wayback Machine] (accessed 15.10.2019).

Grazhdanin. (1873f) No. 13, March 26. Philolog.ru [online] Available at: http://philolog.petrsu.ru/fmdost/grajd/1873/26marN13.htm [archived in Wayback Machine] (accessed 15.10.2019).

Grazhdanin. (1873g) No. 14, April 2. Philolog.ru [online] Available at: http://philolog.petrsu.ru/fmdost/grajd/1873/2aprN14.htm [archived in Wayback Machine] (accessed 15.10.2019).

Grazhdanin. (1873h) No. 15-16, April 16. Philolog.ru [online] Available at: http://philolog.petrsu.ru/fmdost/grajd/1873/aprN1516.htm [archived in Wayback Machine] (accessed 15.10.2019).

Grazhdanin. (1873i) No. 27, July 2. Philolog.ru [online] Available at: http://philolog.petrsu.ru/fmdost/grajd/1873/2julN27.htm [archived in WaybackMachine] (accessed 15.10.2019). 
Grazhdanin. (1873j) No. 32, August 6. Philolog.ru [online] Available at: http://philolog.petrsu.ru/fmdost/grajd/1873/6auN32.htm [archived in WaybackMachine] (accessed 15.10.2019).

Grazhdanin. (1873k) No. 39, September 24. Philolog.ru [online] Available at: http://philolog.petrsu.ru/fmdost/grajd/1873/24seN39.htm [archived in WaybackMachine] (accessed 15.10.2019).

Grazhdanin. (1873l) No. 40, October 1. Philolog.ru [online] Available at: http://philolog.petrsu.ru/fmdost/grajd/1873/1ocN40.htm [archived in WaybackMachine] (accessed 15.10.2019).

Grazhdanin. (1873m) No. 50, December 10. Philolog.ru [online] Available at: http://philolog.petrsu.ru/fmdost/grajd/1873/10deN50.htm [archived in WaybackMachine] (accessed 15.10.2019).

Grazhdanin. (1874) No.9, March 4. Philolog.ru [online] Available at: http://philolog.petrsu.ru/fmdost/grajd/1874/74n09.htm [archived in WaybackMachine] (accessed 15.10.2019).

Submission date: 22.10.2019.

Захаров Владимир Николаевич - доктор филологических наук, профессор, заведующий кафедрой классической филологии, русской литературы и журналистики Института филологии Петрозаводского государственного университета. Адрес: 185910, Россия, г. Петрозаводск, пр-т Ленина, д. 33, каб. 301. Тел.: +7 (8142) 71-96-03. Эл. адрес: zakharov@petrsu.ru

Zakharov Vladimir Nikolaevich, Doctor of Philology, Professor, Head, Department of Classical Philology, Russian Literature and Journalism, Institute of Philology, Petrozavodsk State University. Postal address: Office 301, 33, Lenina Prospekt, 185910 Petrozavodsk, Russian Federation. Tel.: +7 (8142) 71-96-03. Email: zakharov@petrsu.ru

\section{Для циитирования:}

Захаров В. Н. Тезаурусный анализ и проблема атрибуции редакционных статей в «Гражданине» Достоевского (1873-1874) [Электронный ресурс] // Горизонты гуманитарного знания. 2019. № 5. С. 104-116. URL: http:// journals.mosgu.ru/ggz/article/view/1105 (дата обращения: дд.мм.гггг). DOI: 10. 17805/ggz.2019.5.6 